\title{
WETENSKAPSTEORIE IN DIE TEOLOGIE
}

\author{
L.F. Schulze \\ Departement Dogmatologie \\ PU vir CHO \\ POTCHEFSTROOM
}

\begin{abstract}
The scientific character of theology was generally safeguarded by the demand that theology should have a sound philosophical foundation. This still holds true today. The result of this demand is presented here by means of a general overview of the influence of philosophy on thealogy since the Aufkldrung. This is followed by an example of a structuralist exegesis, highlighting the various philosophic, linguistic and psychological motives active in this process. Thirdly, the question about the reliability of scientific knowledge is raised against the background of the madem trend towards relativism. The article concludes with a few guidelines - both negative and positive-for reformed theology.
\end{abstract}

\section{FILOSOFIE EN TEOLOGIE KURSORIES GESIEN}

Die divergensie van die filosofie (en kenteorie) na die Renaissance in die rasionalisme (Descartes) en empirisme (Hume) sou in Kant se "Kopernikaanse omwenteling" opnuut saamgevat word (vgl. bv. Poythress, 1988:27-31). Hiermee sou die Wes-Europese denke van die "mondige mens" sy tipiese stempel ontvang.

\subsection{Kant, Hegel en Schleiermacher}

\subsubsection{Kant}

Kant se "kritiese" filosofie ondersoek die voorwaardes waarvolgens menslike kennis moontlik is - nie die vraag na die inhoud of oorsprong van kennis nie, maar na die struktuur van kennis word primer gestel. So soek hy na aprioriese (d.w.s. aan die ervaring voorafgaande) kennis wat algemeen geldig en noodsaaklik is. In wese word dit 'n struktuuranalise van die bewussyn.

In sy Kritik der reinen Vernunft kom hy dan tot die volgende konklusie: alle kennis begin by die sintuiglike ervaring en die bewussyn orden hierdie chaos van ervaringsindrukke in bepaalde kaders deur die aprioriese kennisvorms. Laasgenoemde word in drie kategorieë onderskei: 
- twee aanskouingsvorms: ruimte en tyd;

- twaalf verstandsvorms, waaronder substansie en kousaliteit;

- drie leidinggewende, hoogste ideë: siel, wêreld en God.

Laasgenoemde drie "orden" geen sintuiglike ervarings nie maar is interne integrasiefaktore van die bewussyn soos die alfabet 'n woordeboek orden. Anders gesê: hierdie psigologiese, kosmologiese en teologiese idees berus nie op werklike empiriese gegewens nie maar op die drang van die rede om alle kennis vanuit samevattende gesigspunte te besien. Hierop kan geen wetenskap gebou word nie omdat die wetenskap die empiriese wêreld ondersoek.

Hiermee is nie alles gesê nie omdat die wetenskap nie alles kan sê nie. Is die mens nie dalk meer as 'n bloot kousaal-gedetermineerde rat in die natuur nie? Dit kan die wetenskap nie sê nie maar alleen die geloof - 'n nie-teoretiese kenbron.

In hierdie konteks staan die bekende woorde van Kant (1899:30): "Ich musste also das Wissen aufheben um zum Glauben Platz zu bekommen." Dit laat ruimte vir 'n verdere ondersoek - die Kritik der praktischen Vernunft. Hierin hou Kant hom besig met die geheim van die mens. Die gedagte dat die mens liggaamlik en geestelik volledig gedetermineer is, word deur die praktiese rede (die sedelike selfbewussyn) weerspreek: die mens is outonome vryheid! So blyk die mens burger van twee wêrelde te wees: 'n nietige element in die ryk van die natuur maar ook'n selfbepalende persoonlikheid in die ryk van die vryheid.

Sedelike handelinge veronderstel nie net vryheid nie maar ook onsterflikheid en God! Wat die teoretiese rede hoogstens kan dink, word eers deur die praktiese rede (sedelike bewussyn) as sodanig geken.

Kant se volgelinge (w.o. Fichte, Schelling, Hegel) het almal by sy kritisisme begin maar hom verbygestreef en weer by die metafisika (wat hy begrawe het) uitgekom. Elkeen sou op sy eie manier die sentrale vraag na die verhouding van natuur en gees oplos.

\subsubsection{Hegel}

Hegel meen dat natuur en gees na mekaar voortgekom het uit iets wat albei voorafgaan, naamlik die idee of die absolute denke. Die hele wêreldontwikkeling van natuurwording, van geestes- en kultuurontwikkeling is fases in die ontwikkeling van die absolute idee, wat van denke tot selfdenke (d.w.s. selfbewussyn en bewussyn van eie vryheid) wil kom. Hierdie ontwikkeling geskied dialekties van tese via antitese na sintese. Die idee as oorsprong van alles is die tese; die natuur as vervreemding van die idee is die 
antitese, terwyl die menslike gees, wat natuur en denke ineen is, die sintese is. Laasgenoemde ontwikkel weer verder: die bewussyn of subjektiewe gees (tese) wat objektiewe gestalte aanneem (objektiewe gees word) in die kultuurprodukte (antitese), kom ten slotte in die selfbewussyn van die absolute gees saam (sintese). Die absolute gees openbaar hom weer dialekties in die kuns (tese), in die religie (antitese) en in die filosofie (sintese). In die kunstenaar, wat die absolute aanskou, in die religieuse mens, wat die absolute envaar (en voorstellings daarvan maak), en veral in die filosoof, wat die absolute dink, bereik die idee sy voorgenome doel: die absolute selfbewussyn. Nes Fichte sè Hegel: As ek dink, dink die absolute eintlik in my (vgl. Kloos: "Ik ben een God in het diepst van mijn gedachten").

Toe Hegel se gedagtes bekend geword het (na 1850), het hy Kant in populariteit ver oortref (vgl. Klapwijk, 1971:18-24).

\subsection{Schleiermacher}

Schleiermacher, in ons geledere deurgaans onbekend (ten spyte van gereelde verwysings na hom), is al bestempel as die grootste gereformeerde teoloog sedert Calvyn. $\mathrm{Hy}$ is inderdaad een van die grotes maar tegelyk ook een van die moeilikstes om te verstaan. Dat volgens hom die godsdiens in die gevoel gesetel is, is oorbekend, maar hoe kom hy daartoe en waarom doen hy dit? Hieroor enkele opmerkings, belig uit twee van sy werke. Een sé iets oor sy etiek, die ander oor sy kenteorie en teologie.

In 1800 verskyn sy Monologen, die etiese pendant van die Reden über die Religion (1799). In profeties-poëtiese taal word die hoofgedagte telkens weer beklemtoon: "Weerspieël op unieke wyse in jou eie persoon die mensheid" - maar dan nie volgens die kategoriese imperatief van Kant nie (hy verwerp dit as onreg aan die adel van die mens) maar eerder na analogie van die natuur. Dit beteken dat die hoogste sedelike ideaal is om die self te vorm tot 'n unieke en onvervangbare individu wat 'n artistiek bevredigende representasie van die mensheid sal wees (Schleiermacher, 1968:79).

In sy Dialektik, wat na sy dood in 1834 verskyn, ontvou hy sy teorie van die kuns van die denke wat, soos vir Plato, oorgaan in kenteorie en metafisika. Denke is bedoel om ons tot kennis te bring. Kennis vereis egter twee soorte korrespondensie: eerstens tussen denke en werklikheid en tweedens tussen denke van verskillende denkers. Eersgenoemde kan alleen verklaar word as ons 'n oorspronklike wedersydse verhouding tussen denke en syn aanneem. Daar is immers in ons denke 'n sekerheid wat 'n fundamentele eenheid van die "opponerende" ideële en reële wêrelde impliseer, anders sou kennis nie moontlik gewees het nie. Om die geldigheid van kennis te stel is ten slotte 'n geloofsoortuiging wat nie bewys kan word nie. Al wat ons kan sé, is: om dit te 
ontken is om die rede self te ontken. Hierdie laaste en universele grond dui ons met twee korrelatiewe name aan: vanuit een gesigspunt is dit God, vanuit die ander die wêreld (Schleiermacher, 1968:94-99).

Ons het hier met 'n moderne en skerpsinnige variasie van die ontologiese Godsbewys te doen.

Op analoë wyse toon Schleiermacher aan dat nie net ons denke nie maar ook ons wil die Absolute (God) veronderstel. Deur die boek loop dan die refrein wat Mackintosh(1964:44) in die volgende woorde saamvat: "... since the idea of God is to be postulated for the satisfaction alike of knowledge and of will, its proper home within our consciousness must be in that which precedes and underlies will and knowledge equally, viz., feeling." (Vgl. ook die aanvangsparagrawe van Der christliche Glaube in Schleiermacher, 1968:20-32).

God en wêreld bestaan onskeibaar tesame. Dink aan die wêreld sonder God en dit het geen eenheid nie; dink aan God sonder die wêreld - dan is die voorwerp van ons denke inhoudloos. Tog is God en wêreld in geen opsig identies nie: die wêreld is die hoogste eenheid wat alle antiteses insluit; God is die hoogste eenheid wat alle antiteses uitsluit. Albei idees is egter transendentaal in die sin dat hulle voorveronderstellings van geldige kennis is, hoewel hulle self nie direk kenbaar is nie. Ons kan God dus nooit ken nie omdat dit 'n begrip is waarvoor ons geen sintuiglike gegewens het nie.

Is dit alles semi-panteistiese filosofie, soos Brunner gese het? Schleiermacher ontken dit heftig. In 'n ope brief aan Lücke ontken hy elke spoor van 'n filosofiese dogmatiek: "I have said repeatedly that Christian doctrine must be set forth in complete independence of each and every philosophical system ... I could never allow that my faith in Christ came from philosophy" (aangehaal deur Mackintosh, 1964:46).

Of hy werklik geleer het wat hy bely het, bly ' $n$ ope vraag. Dit word besonder akuut as hy argumenteer dat die wil van God en die ketting van natuurlike oorsake twee name vir dieselfde ding is. Ten slotte bly die vraag knaag of die filosofie nie tog by hom die botoon gevier het nie. Immers: watter verband is daar tussen die gedagte van 'n onveranderlike kosmiese proses aan die een kant en die Bybelse leer dat die ganse skepping elke oomblik in die hand van die vry en almagtige God is?

Samevattend: By alle verskil in opvatting het Kant, Hegel en Schleiermacher tog dit gemeen dat hulle leer dat die religieuse waarheid nie objektief in die Skrif gegee is nie maar in die mens gevind of uit sy ervaring of deur sy postulate afgelei kan word. 


\subsection{Hegel en die teologie}

By Hegel en sy volgelinge, wat aan godsdienstige voorstellings prioriteit toeken en meen om uit die voorstellings deur dialektiese redenering tot ware en suiwer begrippe te kom, is die volgende grondgedagtes duidelik:

- daar is geen aparte orgaan vir godsdienstige kennis nie - alle kennis kom uit die rede;

- godsdienstige kennis veronderstel dat die bosinlike inderdaad kenbaar is en dat daar vir die bestaan van God, die onsterflikheid van die siel en die realiteit van die Bybelse heilsfeite bewyse gelewer kan word;

- daar is slegs een omvattende wêreldbeskouing wat godsdiens en wetenskap omvat geloof en rede hoort by mekaar;

- godsdienstige en wetenskaplike waarheid, hoewel saaklik identies, verskil van vorm: die godsdiens het voorstellings van dit wat die wysbegeerte in begrippe uitdruk (Bavinck, 1928:41).

\section{$1.3 \quad$ Kant en Schleiermacher}

Nie almal was soos die Vermittlungsteoloë (Rothe, Dorner) en ander (Strauss, Biedermann en Scholten) betower deur die glans van Hegel se spekulatiewe filosofie nie. Sommige het by Kant of by Schleiermacher heil gaan soek. AJbei leer die volgende waarin hulle formeel ooreenstem:

- nie die verstand of rede is die bron en orgaan van godsdienstige kennis nie maar die wil, die hart of die gevoel van die mens;

- omdat die rede wetenskap bedryf maar godsdiens in 'n ander funksie gesetel is, het godsdiens en wetenskap niks met mekaar te doen nie; daarom kan iemand 'n Christen wees wat "neutrale" wetenskap bedryf of kan hy as filosoof deïs of panteïs wees.

Ondertussen is daar tussen Kant en Schleiermacher ook ingrypende verskille. By Kant is die sedelike ervarings op sigself nog nie godsdienstig nie maar die gegewe van waaruit ' $n$ mens verder kan redeneer om ten slotte die bestaan van ' $n$ werklikheid wat aan die godsdienstige voorstellings beantwoord, te postuleer (God en onsterflikheid as postulate van die praktiese rede). So word God uitgerangeer as 'n "grensbegrip"(!) wat vir ons kennis van die wèreld en ons wetenskap en kenteoretiese aktiwiteite nie nodig is nie. Om die wetenskaplikheid van die teologie en die aktualiteit van die godsdiens te red, het Schleiermacher 'n nuwe aprioriese fundering van die godsdiens binne die empiries bestudeerbare werklikheid gesoek en dit in die gevoel van die mens gevind (vgl. Bromiley, 1978:362). Die volstrekte afhanklikheidsgevoel is van huis uit religieus; 
daarom is godsdiens ' $n$ wesenlike bestanddeel van die menslike natuur en is dit die taak van die dogmatiek om hierdie vroom gemoedstoestande te beskryf.

\subsection{Ritschl}

Hierdie nuwe subjektiewe teologie, of dit nou meer eties (Kant) of meer misties (Schleiermacher - die teoloog van die Romantiek!) gekleur was, het in die vroeg 19de eeu groot invloed gehad. Ook Ritschl, wat later teen sowel die begripsfilosofie van die Hegeliane as die bewussynsteologie (ervaringsteologie) van Schleiermacher in verset gekom het, kon aan hierdie stroom geen verandering aanbring nie. Hoewel hy in sy historiese studies groot waardering vir die persoonlikheid kry en gevolglik in sy dogmatiek tot die openbaring van God in die Persoon van Christus terugkeer, beperk hy tog die openbaring tot die bekendmaking van God se wil om sy ryk op aarde te stig. Die oorsprong, wese en bestemming van die dinge bly buite die gesigsveld. Hy onderskei immers tussen synsoordele en waardeoordele (waarmee die teologie uitsluitlik te doen het - 'n interessante prefigurasie van die latere logies- positiwistiese dilemma van die is-ought-kwessie) en bly in gebreke om die kriterium waarvolgens die Christelike teologie beoordeel moet word, aan te gee. Gevolglik gaan sy navolgers in verskillende rigtings uiteen.

\section{Ritschl se opvolgers}

\subsubsection{Die linkervleuel: Hermann}

Aan die een kant is daar Wilhelm Hermann - een van die leermeesters van die jong Karl Barth - wat die geloof van notitia losmaak en bloot as fiducia opvat. Geloof berus nie op enige gesag nie maar kom tot stand deur 'n sedelike ervaring, deur die diep indruk wat die karakter van Jesus op die gemoed maak van elkeen wat na God soek. Die "innerlike lewe" van Jesus (afgesien van sy werke) is die laaste en diepste grond van die geloof. Maar soos ons sedelike ervaring ryker word, neem die inhoud van die geloof toe (vgl. vir dieselfde gedagtes by die jong Barth die aanhaling van Busch in Schulze, 1981:53). Met 'n "geloof" sonder kennis en 'n niksseggende inneres Leben Jesu as sy grond triomfeer die ervaringsteologie - die sedelike ervaring is kenbron van die teologie want die geloofsinhoud word uit die geloof self ontwikkel. In sy poging om Kant en Schleiermacher te sintetiseer het Hermann se aantrekkingskrag vir die jong Barth gelè. 


\section{Die regtervleuel: Kattenbusch en andere}

Aan die ander kant het teoloê soos Kaftan, Wobbermin en Kattenbusch die subjektiwisme van die ervaringsteologie probeer ontkom deur kennis weer as wesenselement van geloof te sien en die objektiewe en normatiewe van die openbaring te erken. Tog word die Skrif nie aanvaar soos dit aangedien word nie maar word dit gesien as "oorkonde van die openbaring" wat na sy omvang en inhoud van die oordeel van die teoloog afhanklik is. "... ook de rechterzijde der school van Ritschl komt de bewustzijns-theologie niet te boven" (Bavinck, 1928:45).

\subsection{Die godsdienshistoriese skool}

'n Ander geslag het Ritschl gekritiseer omdat hy die Kantiaanse skeiding van godsdiens en wetenskap nie konsekwent deurgetrek het nie maar nog teoretiese elemente in die godsdiens aangeneem het en partydig vir die Christendom was. Die knoop moes deurgehak word - aan die een kant is die godsdiens, wat suiwer prakties, 'n inwendige vroomheid en mistiek van die hart is (Schleiermacher); aan die ander kant is die teologie (wat soos alle wetenskappe) sonder persoonlike vooroordeel op eksakte wyse beoefen moet word. Daardeur sal die Christendom in die ry van godsdienste en in die algemeen menslike fenomeen "religie" ingeskakel word. Hier staar die positiwisme met sy teologiese masker van die religionsgeschichtliche Schule ons aan. Op bibliologiese gebied is daar soms knaend maar in uiteenlopende rigtings na fiktiewe "bronne" agter die bron gesoek - Astruc, Geddes, De Wette, Ewald, Wellhausen, Fohrer. ('n Mens wonder net wat van die historiografie as wetenskap sou word as historici op grond van sekere woordgebruike bronne sou gaan rekonstrueer wat agter Van Riebeek se Dagboek sou le.) Soms is kernwoorde van die Bybel na hulle heidense agtergrond herlei en daarmee "aangetoon" dat die Bybel niks besonders is nie maar bloot ' $n$ religie naas ander is en van die ander afgelei kan word. Hiervan is Bousset se Kurios Christos 'n skoolvoorbeeld. Hierin "bewys" hy dat Kurios vir die vroegste Palestynse kerk 'n onbekende term was en eers in Antiochië deur Hellenistiese Christene onder invloed van die misteriegodsdienste aan Hom toegeken is (vgl. hieroor Nash, 1984: 162-169). Dogmaties het die positiwisme in die sisteem van Troeltsch sy kroon bereik.

\subsection{Die historisme: Troeltsch}

Dit is duidelik dat sommige basiese motiewe van die vroeē Aufklärung hier dominant word. Met name geld dit vir Semmler se opvatting dat die dogma as historiese verskynsel gesien moet word, en Lessing se visie op die Christendom as "hoogste" open- 
baring in die ry van godsdienste. Hierdie historiese bewussyn het in die Romantiek van die 19de eeu nuwe impetus gekry (dink aan die Schlegel-broers met hulle geskiedenis van die Duitse taal) en is in die poësie as 'n idealisering van die verlede (of van dit wat ver is) verwoord. ' $n$ Voorbeeld van hierdie verlange na dit wat ver is, word treffend deur Schmidt von Lübeck in sy gedig, "Der Wanderer", verwoord. In hierdie gedig, wat danksy Schubert se toonsetting (op. 4, no.1) voortleef, wel die gedagte na 'n heerlike maar onbereikbare vaderland in die digter op en skiet die gedagte hom te binne:

Dort wo du nicht bist,

dort ist das Glück. (Schubert, s.j.:186)

By Troeltsch verdig die historiese bewussyn tot 'n eksakte positiwistiese metode wat die "vooringenome" dogmatiese metode moet vervang. Die suiwer "historiese metode" met sy drievoudige gesigspunt van analogie, kritiek en korrelasie sien die geskiedenis as 'n kousale ketting van oorsaak en gevolg wat alle ingryping van God uitskakel. Hier word die historiese dimensie van die werklikheid verabsoluteer tot 'n stroom wat alles waarby dit verbyvloei, onherroeplik relativeer en wegbère in die kwalitatief mindere verlede.

\subsection{Die invloed van die historisme}

Hoewel Troeltsch tot die verlede behoort, is sy invloed - ten spyte van sy leer - vandag nog steeds merkbaar. Die historisme, wat volgens Klapwijk (1970:50) niks anders as kultuur-historiese ewolusionisme is nie, is vandag nog in die mees uiteenlopende strominge lewendig. Dit is merkbaar in die eksistensialistiese teologie van Rudolf Bultmann. Sy program van die "ontmitologisering" van die Bybel is gebou op die veronderstelling van die primitiewe verlede wat teenoor die verligte hede staan. Hierdie teëstelling word soms op populère wyse as onderskeiding tussen "verpakiking" en "inhoud" van die evangelie opgedis. In die neo-positiwisme van Hick en Kuitert vind dit gestalte in die stelling dat die geskiedenis die "voorlopige" teologiese uitsprake ten slotte moet verifieer. In die fenomenologiese hermeneutiek verskyn die historisme in die vorm van die fusie van horisonne. Dit het selfs sy neerslag in die wetenskapsteorie soos blyk uit die uitspraak van Kuhn: "Unlike art, science destroys its past" (1977:345). Wat 'n kruisbestuiwing!

\subsection{Karl Barth}

Barth se groot poging om die objektiwiteit van die openbaring te red, moet waardeer 
word. Wanneer hy egter openbaring en Skrif (die menslike getuienis van die openbaring) skei, laasgenoemde oorgee aan die erosie van die historiese kritiek terwyl hy die openbaring self wil veilig stel in die hawe van die Ubergeschichte, skyn ook hy nie te ontkom aan die skisofrenie van die Aufklänung nie. Daarom was Barth se reaksie maar 'n tussenspel in die teologiese ontwikkeling en het hy op sy oudag gekla dat die hele 19 de eeu in die tweede helfte van ons eeu weer terugkeer.

\subsection{Kruisbestuiwing vandag}

Dit is inderdaad so dat die histories-kritiese metode nog deur vele as die vrugbaarste eksegetiese metode beskou word en die klanke van dié godsdienshistoriese skool hoor 'n mens vandag(!) nog soms oor die televisieuitsendings. Dit alles word deur allerlei "nuwighede" soos die language games (Wittgenstein) van strukturalisme of resepsieteorieë deurspek. Per slot van rekening is jou paradigma irrelevant, mits dit maar verklaringsresultate lewer. Die mens word as wetenskaplike 'n groepswese, geskoei deur die dissiplinêre matriks van sy vak - 'n identiteitslose performer.

\section{STRUKTURALISTTES-PSIGOLOGIESE EKSEGESE - 'N VOORBEELD}

Hoe lyk die resultaat wanneer een van die baie taalteorieë as eksegetiese metode toegepas word? Soms heel verrassend, soos blyk uit Via (1976:1-32) se verklaring van die gelykenis van die onregverdige regter. Sy aandurf van hierdie bekende gelykenis dra die veelseggende opskrif: "The parable of the unjust judge: a metaphor of the unrealised self".

Dit is nie moontlik om ' $n$ volle analise van hierdie lang en geleerde artikel te gee nie. Enkele grepe wat iets van sy metode en uitgangspunt (in hierdie volgorde) belig, word uitgelig.

$\mathrm{Na}$ 'n lang inleiding (1976: 1-5, waaroor later meer) begin Via sy strukturalistiese eksegese met 'n bespreking van 'n funksionele analise waarin eerstens storie en diskoers (teks) onderskei word: "Our unit is a narrative (more story than discourse...) told by a character (Jesus) and enclosed between two parallel story statements made by the Lukan narrator" (1976: 5). Vervolgens word die taalfunksies van verhaal en "story statements" met behulp van Jakobson se kommunikasiemodel onderskei: "... the parable itself exercises the poetic linguistic function ... On the other hand, the two interpretations which surround the parable exercise the metalinguistic function: they are texts about a text" (1976: 6). 
Anders as wat ons doen, word die gelykenis hier uit sy onmiddelike konteks uitgehaal en op sigself betrag. Skematies kan dit so voorgestel word:

\section{Metateks}

\section{("story statements")}

1 Jesus het vir hulle 'n gelykenis vertel om duidelik te maak dat 'n mens altyd moet aanhou bid sonder om moedeloos te word. ${ }^{2} \mathrm{Hy}$ bet gese:

\section{Teks}

"In 'n sekere stad was daar 'n regter wat geen eerbied vir God of agting vir 'n mens gehad bet nie. ${ }^{3} \mathrm{En}$ in dieselfde stad het 'n weduwee gewoon wat hom bertaaldelik kom vra bet: 'Doen aan my reg in my saak teen my teenparty.' 1 'n Tyd lank wou by nie, maar later het by vir homself gesé: Vir God het ek wel geen eerbied nie, en aan 'n mens steur ek my nie, 5 maar aangesien hierdie weduwee so aanhou om my lastig te val, sal ek haar in baar regsaak help, anders kom klap sy my op die ou end ook nog:

\section{Metateks}

6 Toe se die Here: "Hoor wat se die onregverdige regter. ${ }^{7}$ Sal God dan nic aan sy uitverkorenes, wat dag en nag to bom roep, reg doen nie? Sal Hy hulle lank laat wag? ${ }^{8}$ Ek st vir julle: $\mathrm{Hy}$ sal bulle belp, en gou ook!"

Hoe Via met Bremond se onderskeiding van die drie fases in die ontvouing van die verhaal en met Greimas se aktansiële analise werk, laat ons daar. Ten slotte kom hy by Jung uit en nadat enkele begrippe (bv. die self, die - persoonlike en kollektiewe onbewuste, die argetipes) verduidelik is, sluit hy sy bespreking van die gelykenis af met die opskrif "The unjust judge: a Jungian interpretation". Dit lei tot sy finale konklusie (Via, 1976:27):

If the judge bad acted differently, be might have overcome his moral and existential estrangement and thereby his religious alienation. But be acted as we bave seen him act, and God is kept in the margin as one who does not have to be revered. Or, ego and anima are not joined, and the self remained unrealized.

In die inleiding word sy (Via,1976:6) uitgangspunt duidelik gestel. Hy gaan uit van "the phenomenological framework", soos uitgewerk deur Merleau-Ponty, "within which I will place the structuralist categories that will be used to interpret this parable....". Die doel van die fenomenologiese metode is om die mens weer tot 'n direkte ervaring van die wêreld te bring. Die fenomenologie bied egter nie 'n beskrywing van die wêreld soos dit is nie maar soos ons dit ervaar. Persepsie geskied immers altyd vanuit 'n bepaalde hoek of binne ' $n$ bepaalde horison. 
Vervolgens word sy eie perspektiefkeuse duidelik omskryf (Via, 1976:2-3):

What I am bracketing in as my vantage point for reading, which defines the mind of this reader ... is certain structuralist categories and the Jungian concept of the self or the ego-self relationship. The analysis of narrative functions and actants has as its purpose the displaying of the network of relationships and movements which are to be translated into psychological terms, more specifically into some components and movements of the self as understood by Jung. The bracketing in of Jungian categories simply means that the subject matter to be looked for is the dynamics of the self.

Soos reeds aangetoon, bereik Via dan ook inderdaad die doel wat hy hier in die vooruitsig stel!

Al hierdie geleerdheid laat 'n mens dink aan Hans Frei se kritiek. Comstock (1989:745746) som dit so op:

Frei objects to the practitioners of the existentialist hermeneutic (be they Americans, Germans, Freudians, or structuralists) for allowing their "general theory" to "dictate to" their exegetical practice. He makes no bones about his displeasure with these methods; they are "useless", operating at an "ethereal level", inadequate as guides for interpreting the actual stories of the New Testament.

Om dit nog skerper te sê, kan Terry Eagleton (1983:96) dit namens ons doen:

... structuralism is a calculated affront to common sense. It refuses the "obvious" meaning of the story and sceks instead to isolate certain "deep" structures in it ... It does not take the tex at face value, but "displaces" it into a quite different kind of object.

Via (976:3) se uitgangspunt en sy beroep op Heidegger dat "the interpreter may have to use 'violence' on the text in order to 'show what does not stand in the words and is nevertheless said'" kan, soos sy eksegese hierbo aantoon, alleen lei tot subjektiewe allegorisering wat die sin van die Skrif, soos Lukas dit verhaal, misdui. Dit is asof Calvyn ook vandag sy skerp kritiek op allegorisering lug: "... dit is 'n verderflike dwaling dat die mense gedink het dat Skriflesing nie alleen tevergeefs nie maar selfs skadelik sal wees, as dit nie tot allegorieë deurgetrek word nie. Hierdie dwaling was die oorsaak van baie euwels. Dit het immers nie alleen ' $n$ losbandigheid om die egte betekenis van die Skrif te verkrag toegelaat nie, maar namate elkeen daarin brutaler was, is hy ook as 'n uitnemender verklaarder van die Skrif beskou. So het baie skrywers van die ou tyd met die heilige Woord van God die spot gedryf ... net asof hulle met 'n bal speel" (Komm. 2 Kor. 3:6; Afr. in Calvyn, 1986:465, n. 129). Dit lyk dus nie of die tye veel verander het nie.

Ten slotte is dit interessant om op te merk dat die oogmerke wat Nethersole (1982:158-159) vir die hermeneutiek in die algemeen uitstippel, nog altyd die basis van die 
gereformeerde hermeneutiek was: "If literary hermeneutics is to become a clearly defined theory, it will have to reflect upon pre-conditions for understanding, not in a general mode, but in a particular one, appropriate to its subject matter". Juis hier het ons nog altyd die Gees se verligting as 'n "pre-condition for understanding" van die Skrif as unieke gegewe erken.

\section{HOE SEKER IS "WETENSKAPLIKE" KENNIS?}

Stoker was nog oortuig dat wetenskaplike kennis soveel as moontlik gekontroleerde en geverifieerde kennis is. Gevolglik was dit betroubare kennis. Hieragter la natuurlik die veronderstelling dat die wêreld kenbaar is en die mens kenvermoëns het om betroubare kennis op te doen. Vandag word hierdie naïewe "korrespondensieteorie" van waarheid bevraagteken. Sedert Lessing en Hegel het die historisme die spook by ons opgetower dat alle waarheid "tydgebonde" is. Die neo-positiwisme met sy uitgesproke a-historiese karakter het in ons eeu weer gepoog om 'n eksakte (natuurwetenskaplike) wetenskapsmodel daar te stel en die rol van die filosofie is teruggedring tot dié van waghond, wat die waarheidsgehalte van die wetenskaplike uitsprake logies en empiries moes toets. Die impetus van die historisme kon egter nie gestuit word nie en kom nog steeds in vele gedaantes voor. Gekombineer met die sosiologie word die wetenskapsbeoefening vandag gesien as ' $n$ relatiewe en voorlopige saak, omvat deur ' $n$ tradisie en die groep met sy heersende paradigmas. Die filosofie bly sy rol op die metavlak speel en verloop grootliks in wetenskapsfilosofie en kenteoretiese bespiegelinge. Die korrespondensieteorie van waarheid is agterhaal en foundationalism as 'n dogmatisme is uit. Net jammer dat daar gepoog word om dit te kelder met die oud-modiese argumente van die skeptikus, Pyrrho, en sy skool.

\subsection{Skeptisisme in verlede en hede}

Pyrrho het by Protagoras aangesluit. Laasgenoemde het reeds die subjektiewe aard en gevolglike onbetroubaarheid van sintuiglike waarneming vir die verkryging van algemeen geldige kennis na vore gebring. Long (1974:79) vat dit soos volg saam: "Truth can only be relative; what is true for me - that the wind feels cold - is true; but this says nothing about the temperature of the wind in itself or how it feels to you." By die skeptici word dit 'n kenteoretiese uitgangspunt ("...Pyrrho declared that things are equally indistinguishable, unmeasurable and indeterminable" - Long, 1974:79) en selfs 'n metode om die etiese ideaal van onversteurbaarheid (vgl. die Stolsyne) te bereik:

Scepticism is an ability which sets up antitheses among appearances and judgments in any way whatever: by scepticism, on account of the "equal weight" which characterizes opposing states of affairs and arguments, we arrive first at "suspension of judgment", and second at "freedom from 
disturbance". (Long, 1974:75.)

So tipeer Sextus Empiricus, die Griekse geneesheer van die tweede eeu, hierdie filosofie.

Nou kom Wolterstorff (1976:49-50) met dieselfde tipe argumente om foundationalism af te skiet:

In short, I may believe that something is appearing brown and desk-like to me. But I do not know that indubitably. In retreating to the more guarded claim that I am being appeared to brownly and desk-likely $I$ bave perhaps arrived at what we are looking for - an item of indubitable knowledge. But notice what it is - a claim about myself and my state of consciousness. Along the way we have discarded singular propositions about physical objects from the body of indubitables, and thus from the foundation.

Die Grieke het hierdie metode gebruik om by 'n etiese ideaal uit te kom; Descartes om die vaste grondslag van wetenskaplike kennis te bekom; tans word dit ingespan om die relatiwiteit en onsekerheid van alle objektiewe kennis aan te toon.

\subsection{Samevatting in 'n beeld}

'n Beeld het sy beperkings. Tog wil ek dit waag om iets van die huidige situasie met 'n beeld te verduidelik. 'n Jongman ontvang 'n liefdesbrief van 'n meisie op wie hy reeds lank verlief is. Hy het twee opsies: hy kan (voorwetenskaplik) die brief met blink oe teen hom vasdruk in die wete dat sy hom lief het; of hy kan probeer om bo alle twyfel sekerheid van die toedrag van sake te kry deur die wetenskap in te span. Hy raadpleeg sy vriende. Psigoloog A se aan hom dat jong meisies se gevoelens baie labiel is en dat hy nie te veel daarop kan staatmaak nie. Psigoloog B meen dat 'n aangrypende liefdesverhaal wat die meisie gelees het (of ' $n$ film) die aanleiding tot die skryf van die brief was (stimilus-respons). Sosioloog $\mathrm{C}$ meen dat 'n bepaalde groepsdinamiek en haar begeerte om nie by haar maats agter te staan nie maar aan 'n bepaalde rolverwagting te voldoen, haar genoop het om 'n kêrel te soek. Afhangende van die standpunt wat hy huldig, sal literatuurwetenskaplike D se dat die jongman die brief as 'n outonome teks moet lees; of dat sy verstaanshorison (wat kan verander) sal bepaal hoe hy die brief interpreteer; of dat hy moet onthou dat sy interpretasie nie noodwendig met die bedoeling van die sender sal ooreenstem nie. Filosoof $\mathrm{E}$ sê aan hom: voor jy bly word oor die brief, moet jy jou eers afvra: hoe verstaan 'n mens; watter metodes moet ek gebruik om reg te verstaan; watter control beliefs kleur en verongeluk gevolglik die regte verstaansproses? Ons kan maar hier met 'n goeie gewete byvoeg: ensovoorts, ensovoorts. Wat moet ons jongman van die magtige wetenskap dink? Geen wetenskaplike kon hom sekerheid oor die brief gee nie. As hy naief en voorwetenskaplik 
optree, sou hy later 'n ring vir haar vinger gaan soek. As hy wetenskaplik optree, sou hy haar afse omdat hy nie weet wat haar motiewe vir die skryf van die brief was nie; hy nie weet of hy die brief reg interpreteer en of sy interpretasie in die toekoms nog geldig sal wees nie, en derdens omdat hy in die geheel nie seker is of hy reg verstaan en die regte uitgangspunte hiervoor het nie en gevolglik twyfel of kommunikasie werklik moontlik is. Gelukkig tree die mens in die dinge van die liefde en van God meesal "voorwetenskaplik" op en word hierdie naïewe sekerheid die grondslag vir latere nadenke.

Hiermee is reeds gesè dat bogenoemde beeld met die nodige aanpassings ook kan dien om ons verhouding met die God van die verbond te belig. Vanuit hierdie gemeenskap met God kan en moet die lig val op ons teologiese bedryf en ons wetenskapsbeoefening in die algemeen. Ons kan egter nie van hieruit terugura na die filosofiese of kenteoretiese veronderstellings of control beliefs wat daaraan ten grondslag lê nie. Die rede hiervoor is eenvoudig: God self bring hierdie verhouding deur die krag van sy Woord en Gees tot stand. Voor hierdie krag kapituleer ons met ons voorveronderstellings en kenteorieë en al.

Calvyn het hierdie oudmodiese foundationalism duidelik geleer. In sy uitnemende artikel oor Calvyn se kenteorie som Torrance (1964:97) dit soos volg op:

If we are really to know God truly we must he emancipated from self-will for self-will determines de profundis all our own ways of knowing and thinking. We need a truth that will set us free from ourselves, otherwise we ourselves with all our preconceptions, prejudgments and inventions, will distort knowledge of God and from the very start convert it into untruth.

\section{RIGLYNE}

- Wanneer ons kyk na die huidige tendens van versubjektivering en relativering van die wetenskap (sosiale paradigmavorming, verstaanshorison, ens.; vgl. ook Bernstein,1983:171 e.v.) kan 'n mens toestem tot die siniese formulering van 'n wet wat die hoofkarakter in Pirsig (1984:107) se boek soos volg stel: "The number of rational hypotheses that can explain any given phenomenon is infinite". Daarmee is wetenskap as wete, soos ons jongman uitgevind het, uitgesluit, in die woorde van Pirsig: "If true, that law is not a minor flaw in scientific reasoning. The law is completely nihilistic. It is a catastrophic logical disproof of the general validity of all scientific method!" (1984:108).

- Ook oor die historisme, wat die waarheid tydgebonde ag, het die skerpsinnige Pirsig 'n verdoemende oordeel: die opvatting dat waarheid ' $n$ funksie van tyd is, "would annirilate the most basic presumption of all science" (Pirsig, 1984:108). Dit is 
ironies om te sien dat die wetenskapsfilosofie in ons tyd van kennisontploffing en tegnologiese vooruitgang tog besig is om die fondamente van die wetenskap te ondergrawe. In die woorde van Swanepoel (1990:30): "Ten spyte van die geweldige kennisuitbreiding is daar tans 'n magdom teoretiese raamwerke wat hulleself aandien as die beste kandidaat om die probleme binne die vakwetenskappe die beste op te los" (p.13). Tereg merk hy verder op dat dit selde gebeur dat een paradigma in die geesteswetenskappe dominansie verkry. As 'n mens in die kategorieë van Spengler (Untergang des Abendlandes) wil praat, sou 'n mens kan sê dat die geskiedenis homself herhaal. $\mathrm{Na}$ die bloei van die filosofie vanaf Thales tot Aristoteles versand dit immers in 'n pragmatiese etiek wat of panteisties (die Stoa) of hedonisties (Epikurus) of skepties gekleur was en gaan ten slotte onder in die sintetiese panteïsme van die neoplatonisme. Miskien is dit simptomaties van ons tyd dat selfs in die gereformeerde teologie in die algemeen die aandag op die etiese en die "praktiese" gekonsentreer is. Origens is in ons wêreld genoemde tendense in die panteisme van die New Age, die hedonisme van die utilitarisme ("the greatest happiness of the greatest number") en in sy wetenskaplike relatiwisme duidelik sigbaar.

- Die teologie sal op hoogte moet bly met alles wat op die wetenskaplike markplein aangebied word om die invloed daarvan in die teologie te onderken; om in 'n openheid wat aan alle -ismes vreemd is, van die waarheidsmomente van almal te leer, sonder om in hulle eensydige verabsolutering van 'n aspek van die geskape werklikheid te verval.

- Omdat die teologie reeds vanaf sy kinderskoene deur die filosofie beīnvloed is, lyk Spykman(1988:140) se voorstel aanloklik: The most appropriate prolegomena to a Reformed dogmatics is a Christian philosophy which arises from the biblical worldview". Ons moet egter bedink dat die invloed van die filosofie juis in die omvang van die prolegomena reflekteer en dat hoe omvangryker die prolegomena geword het, des te armsaliger het die inhoudelike dogmatiek geword (Bavinck, 1928:81-82). Wat Bavinck oor die rasionalisme opgemerk het, bloei in ons dag weer in volle glorie. Tereg merk Kamphuis (1988:7-8) oor hierdie voortdurende soul searching op die metavlak op: " ... er is reden hier te spreken van een ziekte-symptoom van de huidige theologie". Les bes moet ons kyk na Spykman se eie presisering van wat sy voorstel inhou: "Theology's specific mandate is to focus upon the confessional (pistic,faith) aspect of revelation and our response to it, as given in created reality" (1988:150). Hier is baie wat onduidelik is: het die openbaring 'n konfessionele aspek of is die konfessie die kerk se antwoord op die openbaring? Hoe kan ons dan antwoord op die konfessionele aspek van die openbaring? Wat is die draagwydte van "as given with created reality"? Impliseer dit 'n natuurlike teologie of word die diskrepansie tussen teologiese en filosofiese taal - iets wat nie hoort te bestaan nie - 
hier sigbaar?

- Ek sou Spykman se stelling wou amendeer: "The most appropriate prolegomena to a Reformed dogmatics is a Refurmed theology". Dit het natuurlik implikasies vir die ensiklopedie van die wetenskappe waarop hier nie ingegaan kan word nie. Hier lê ook een van die verskilpunte trssen menige teoloog en filosoof wat nog verder uitgepraat moet word - op die basis van ons gemeenskaplike voorwetenskaplike geloof. Eers daarna sal 'n mens kan besin oor die moontlikheid en sinvolheid al dan nie van teorievorming in die teologie.

- Die verwagting om die wetenskaplikheid van die teologie met behulp van 'n filosofiese grondslag te red, blyk uit bostaande terleurstellend te wees. Die ideale van die godsdienshistoriese skool toon duidelik dat sodanige poging om die wetenskaplikheid van die teologie te beskerm, steeds tot 'n onaanvaarbare dichotomie van lewe (geloof) en wetenskap gelei het. Gepaard daarmee word die kloof tussen naïewe en wetenskaplike kennis gevind. Hier is gestel dat wetenskaplike kennis op die naïewe, voorwetenskaplike kennis moet rus. So alleen kan die eenheid van die lewe van die mens (hier in die besonder van die wetenskaplike) bewaar word en kan die gereformeerde teologie die (voorwetenskaplike) geloof van die kerk van God voed. Die enigste alternatief wat die geskiedenis toon, is dat die teologie as "outonome wetenskap" die geloof van die kerk ondergrawe het.

\section{BIBLIOGRAFIE}

BAVINCK, H. 1928. Gereformeerde Dogmatiek Dl.1, 4de druk. Kampen : Kok.

BERNSTEIN, RJ. 1983. Beyond objectivism and relativism: Science, hermencutics and praxis. Oxford : Basil Blackwell.

BROMILEY, G.W. 1978. Historical theology. Grand Rapids : Eerdmans.

CALVYN, J. 1986. Institusie van die Christelike Godsdiens, boek 2. Vert. H.W.Simpson. Potchefstroom : CJBF.

COMSTOCK, G.L. 1989. Truth or meaning: Ricoeur versus Frei on biblical narrative. Hervormde Teologiese Studies, 45(4):741-766.

EAGLETON, TERRY 1983. Literary theory. An introduction. Oxford ; Basil Blackwell.

KAMPHUIS, B. 1988. Klare taal. Barneveld : De Vuurbaak.

KANT, 1. 1899. Kritick der reinen Vernunft. Herausg. K. Vorlander. Halle a.d. S : Otto Hendel.

KLAPWUK, J. 1970. Tussen historisme en relativisme. Assen : Van Gorkum.

KLAPWUK, J. 1971. Oriēntatie in de nieuwe filosofie. V U Amsterdam : Filosophisch Instituut.

KUHN, T.S. 197. The essential tension. Chicago : University of Chicago Press.

LONG, AA. 1974. Hellenistic philosophy. London: Duckworth.

MACKINTOSH, H.R. 1964. Types of modern theology. London: Collins.

NASH, R.H. 1984. Christianity and the Hellenistic world. Grand Rapids : Zondervan. 
NETHERSOLE, R. 1982. Literary hermeneutics: a theory for understanding lexts. (In Ryan, R. \& Van $\mathrm{Zyl}$, Seds. An introduction to contemporary literary theory. Johannesburg : Donker. p. 147160.)

PIRSIG, R.M. 1984. Zen and the art of motor cycle maintenance. (Corgy edition).

POYTHRESS, V.S. 1988. Science and beremeneutics. Grand Rapids : Zondervan.

SCHLEIERMACHER, F.D.E. 1968. Schleiermacher-Auswahl. Herausg. H. Bolli. München : Siebenstern.

SCHUBERT, F. s.j. Gesänge. Band 1. New York : Peters.

SCHULZE, L.F. 1981. Teologic in stroomversnelling. Polchefstroom : Potchefstroomse teologiese publikasies.

SPYKMAN, G.J. 1988. Christisn philosophy as prolegomena to Reformed dogmatics. (In Wethmar, C.J. \& Vos, C.J.A. eds. 'n Woord op sy tyd. Pretoria : NG Kerkboekhandel. p.137-155.)

SWANEPOEL, J. 1990. T.S. Kuhn en die teologie. Seminaar oor wetenskapsteorie in die teologie. Lesing gehou gedurende Mei 1990 - PU vir CHO. (Ongepubliseer.)

TORRANCE, T.F. 1965. Knowledge of God and speech about him according to John Calvin. (In Mehl, R. ed. Regards contemporaines sur Jean Calvin. Paris : Presses universitaires. p. 7-98.)

VIA, D.O. 1976. The parable of the Unjust Judge: A metaphor of the unrealized self. (In Patte, D. ed. Semiology and parables. Pittsburg: Pickwick Press. p. 1-32.)

WOLTERSTORFF, N. 1976. Reason within the bounds of religion. Grand Rapids : Eerdmans. 
